\title{
FLUID EVOLUTION AND GOLD DEPOSITION AT THE CUIABÁ MINE, SE BRAZIL: FLUID INCLUSIONS AND STABLE ISOTOPE GEOCHEMISTRY OF CARBONATES
}

\author{
ROBERTO PEREZ XAVIER ${ }^{1}$, CATARINA LABOURÉ BENFICA TOLEDO ${ }^{1}$, \\ BRUCE TAYLOR ${ }^{2}$ AND ALFONSO SCHRANK ${ }^{1}$.
}

\begin{abstract}
The gold-bearing quartz-carbonate vein deposits of the Cuiabá Mine, northern sector of the Quadrilátero Ferrífero, State of Minas Gerais, SE Brazil, are hosted by a sequence of banded carbonaceous metasedimentary rocks within tholeiitic basalt flows of the Archean Rio das Velhas Greenstone Belt. A regional greenschist metamorphic grade characterizes rocks in this section of the Belt. Episodes of hydraulic fracturing enhanced the focussing of fluids percolating along the host primary layering, which promoted pervasive carbonatization and sulfidation associated with crosscutting fractures and quartz-carbonate veins/breccias. The gold mineralization is closely related to the sulfiderich zones. Fluid inclusion investigations show that the mineralizing fluids were dominantly aqueous, of low salinity (3-6 wt.\% NaCleq.), with variable concentrations of $\mathrm{CO}_{2}(0-11.4 \mathrm{~mol} \%), \mathrm{CH}_{4}(1.5-10.2 \mathrm{~mol} \%)$, subordinate $\mathrm{N}_{2}(0-0.7 \mathrm{~mol} \%)$, and traces of $\mathrm{H}_{2} \mathrm{~S} / \mathrm{HS}^{-}$. Carbonates in the carbonaceous host rock display heavier $\delta^{13} \mathrm{C}$ compositions $(-4.3$ to $-0.2 \%)$ than carbonates in the gold-related, carbonate-sulfide altered zones and associated veins and breccias $(-8.1$ to $-5.5 \%)$. The range of carbonate $\delta^{18} \mathrm{O}$ values in the carbonaceous host rock $\left(12.8\right.$ to $16^{\circ}$ \% is broadly similar to the carbonates in the mineralized zones $(10.6$ to $15.2 \%$, with a slightly larger variation in the latter. Collectively, fluid inclusion and carbon isotope data indicate that: (1) the mineralizing fluid was originally composed of a $\mathrm{H}_{2} \mathrm{O}-\mathrm{CO}_{2}$ solution, with significant concentrations of $\mathrm{CH}_{4}$ added via hydrolysis of the carbonaceous matter during vein-fluid/wallrock interaction; $(2)$ sedimentary carbonates, probably of marine origin, are readily distinguished from those carbonates formed by reaction between $\mathrm{CO}_{2}$-bearing vein fluids and wallrocks; (3) gold-related vein-fluid $\mathrm{CO}_{2}$ was relatively homogeneous in isotopic composition, suggesting equilibration with carbonate and reduced carbon reservoir (e.g. mantle-derived magma); (4) gold deposition may have been triggered by a sharp decrease in $f \mathrm{O}_{2}$ caused by the $\mathrm{CH}_{4}$ enrichment of the fluid.
\end{abstract}

Keywords: hydrothermal alteration, gold mineralization, Cuiabá Mine, fluid inclusions, carbon isotopes.

INTRODUCTION The Cuiabá Mine is one of the most important gold-producing mine in the northern sector of the Quadrilátero Ferrífero, State of Minas Gerais, SE Brazil, with an output of $45000 t$ of ore monthly, at a mean grade of $8.4 \mathrm{~g} / \mathrm{t}$, and reserves estimated at $70 \mathrm{t}$ of $\mathrm{Au}$ (Vial 1988). The gold mineralization is mainly hosted by a 5 to $15 \mathrm{~m}$ thick sequence of banded carbonaceous metasedimentary rock, metamorphosed in the greenschist facies, within an Archean mafic volcanic sequence forming the base of the Rio das Velhas greenstone belt (Nova Lima Group; Fig 1A). This rock consists of a rhythmic alternation of dark, white, and ocher-colored, millimeter- to centimeter-thick bands, rich in amorphous carbonaceous material, fine-grained quartz, and carbonate, respectively. It has been generally referred to in the literature as a banded iron formation or banded ferruginous metachert (Vial 1980; Ribeiro-Rodrigues 1998; Lobato et al. 1998).

The volcano-sedimentary sequence at the mine underwent deformation at different crustal levels, during three successive phases: $\mathrm{D}_{1}$ and $\mathrm{D}_{2}$ phases developed in a ductile to ductile-brittle regime, under compressive stress oriented in the SE-NW direction, with tectonic transport from SE to NW; $\mathrm{D}_{3}$ structures were formed in a brittle-ductile regime and reflect the action of E-W- oriented compressive stresses. The structural framework of the deposit is controlled by a large anticline $\left(\mathrm{F}_{2}\right)$, with an overturned northern limb outlined by the folding of the primary bedding (Vial 1980). This anticline shows a penetrative $S_{2}$ axial plane foliation and presents a tubular geometry with the apex closure pointing to the northwest direction and axis inclined to about $30^{\circ}$ to the southeast (Toledo 1997; Fig. 1B).

The gold mineralization occurs closely associated with carbonatesulfide altered zones that envelop breccias and quartz-carbonate veins. Carbonatization is defined by the precipitation of $\mathrm{Ca}-\mathrm{Fe}-\mathrm{Mg}$ carbonates at the expense of the carbonaceous matter, which is evidenced by the appearance of bleached zones around quartz-sulfide veins, whereas sulfidation is characterized by the formation of banded to massive aggregates of pyrite \pm pyrrhotite \pm arsenopyrite that replace carbonates along the sedimentary layering (Toledo 1997).

This paper addresses the question of the fluid-carbon interaction at the Cuiabá Mine, particularly the influence on the chemical and isotopic composition of the fluid involved in the carbonate-sulfide alteration and deposition of the gold, by means of fluid inclusion and carbon stable isotope studies.

SAMPLED SELECTED AND ANALYTICAL PROCEDURES

A fluid inclusion investigation was carried out on 3 doubly polished sections: two of a $D_{1}$-related quartz-sulfide breccia and one of a $S_{2}$ foliation - parallel quartz-carbonate vein, all representative of the Fonte Grande Sul ore body, level 7 (underground) of the Cuiabá Mine. Microthermometry and Laser Raman microspectroscopy (LRM) measurements of inclusion fluids hosted by quartz were performed on a LINKAM THMSG600 stage and on a Jobin Yvon T64000 Laser Raman Spectrometer, respectively, at the Fluid Inclusion Laboratory, Institute of Geoscience, State University of Campinas (UNICAMP). The stage was calibrated using synthetic fluid inclusions to a precision of $\pm 0.3^{\circ} \mathrm{C}$ for freezing runs down to $-56.6^{\circ} \mathrm{C}$ and to $\pm 3^{\circ} \mathrm{C}$ for heating runs up to $500^{\circ} \mathrm{C}$

The stable isotope ratios of ${ }^{13} \mathrm{C} /{ }^{12} \mathrm{C}$ and ${ }^{18} \mathrm{O} /{ }^{16} \mathrm{O}$ were determined on carbonates separated from 3 samples of the banded carbonaceous metasedimentary host, 11 samples of the ore zones (e.g. Fonte Grande Sul, Serrotinho, Galinheiro and Balancão ore bodies), and 2 barren samples, including a quartz-carbonate-sulfide vein and a carbonate veinlet.

X-ray diffraction analyses of the investigated samples identified ankerite, siderite, calcite and dolomite. In the carbonaceous host, calcite and siderite are common, whereas ankerite very subordinate. Within the carbonate-sulfide-altered zones, and associated breccia and veins, ankerite and siderite predominate, accompanied rarely by dolomite and calcite. Calcite seems to be the main carbonate type in the barren veins.

Samples were prepared for isotopic analysis using the standard phosphoric acid technique (at $25^{\circ} \mathrm{C}$ and $50^{\circ} \mathrm{C}$ ) of McCrea (1950) to release $\mathrm{CO}_{2}$ for mass spectrometric analysis. As the reaction rates are dependent ${ }^{2}$ upon the types of carbonate in the sample, the $\mathrm{CO}_{2}$ was collected at different times according to the carbonate species present in order to avoid a mixture of $\mathrm{CO}_{2}$ from different sources, following the procedure in Al-Assam et al. (1990). Cryogenically purified CO was analyzed for its isotope composition in a Finnigan MAT 252 mass spectrometer at the Geological Survey of Canada, in Ottawa. The isotope ratios of ${ }^{13} \mathrm{C} /{ }^{12} \mathrm{C}$ and ${ }^{18} \mathrm{O} /{ }^{16} \mathrm{O}$ are reported in the usual $\mathrm{d}-$ terminology, expressed in per mil $(\%)$, relative to V-PDB and VSMOW standards, respectively. The isotopic results are organized in Table 1, with a reproducibility of the d-value in the order of $\pm 0.1 \%$.

FLUID INCLUSIONS Fluid inclusions interpreted of primary nature are abundant in quartz grains of the investigated samples, where they commonly occur as large intragranular groups, independent of any microstructures, and, occasionally, as isolated inclusions. The fluid inclusions generally contain two phases at room temperature, an aqueous liquid and a vapor phase (bubble), which show relatively constant phase-volume ratios in individual groups (5\% to $10 \%$ variation). A few inclusions also display solid phases, either a 
(a)

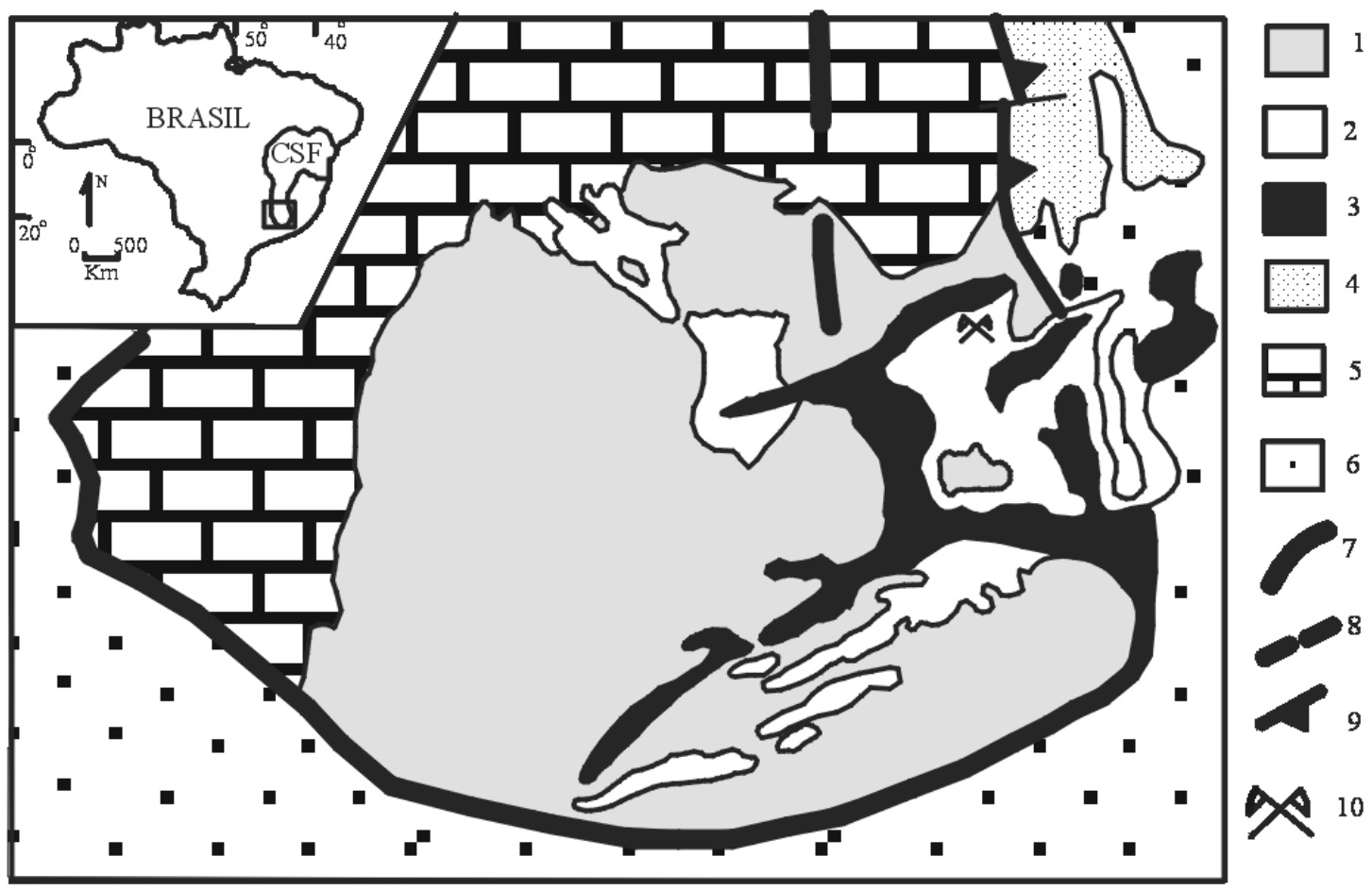

(b)

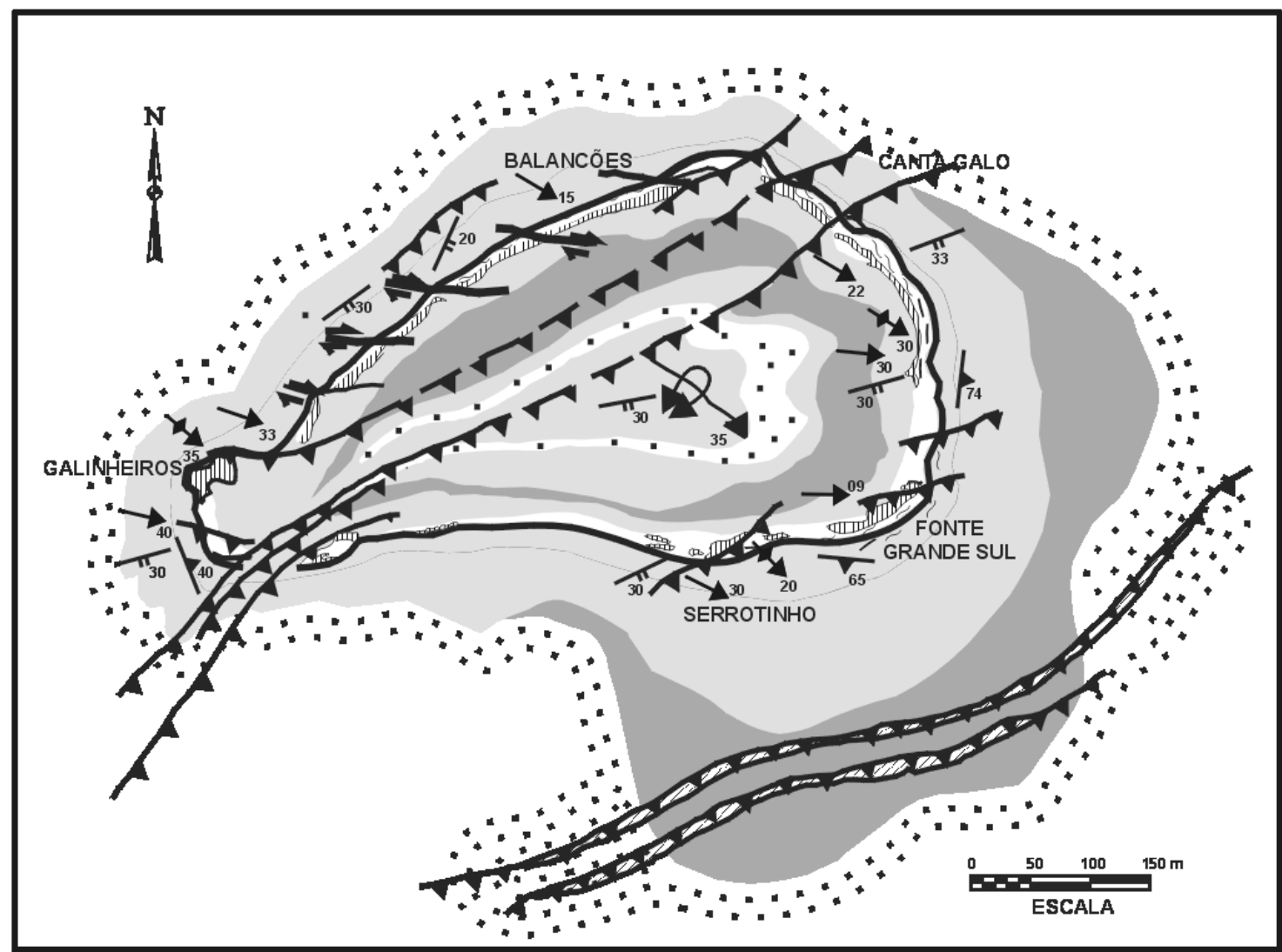

$\because:=$
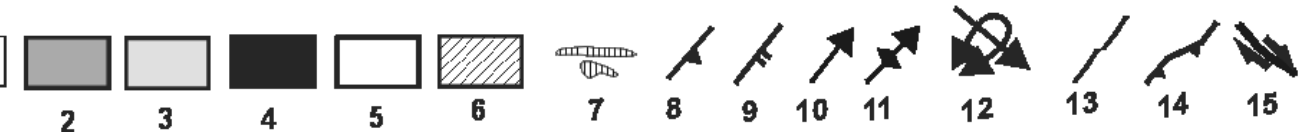

Figure 1-(a) Simplified geologic map of the Ouadrilátero Ferrifero. Legend: 1. Granite-gneiss terrains; 2. Archean greenstone belts; 3. Minas Supergroup; 4. Espinhaço Supergroup; 5. São Francisco Group; 6. Terrains strongly affected by the Brasiliano (Pan-African) Event; 7. Limit of the Brasiliano Event influence zone; 8. Normal faults; 9. Thrust faults; 10. Cuiabá Mine; CSF - São Francisco Craton. Modified from Marshak and Alkmin (1992). (b) Simplified geologic map of the Cuiabá Mine, level 3.1. Turbidite sequence; 2. Metabasalt; 3. Altered zones in metabasalts; 4. Carbonaceous phyllites; 5. Banded carbonaceous metasedimentary rock; 6. $S_{2}$ foliation-parallel quartz veins; 7 . Orebodies; $8 S_{1}$ foliation parallel to primary bedding; $9 . S_{2}$ foliation; 10 . Stretching and mineral lineation Lm $\mathrm{L}_{2} ; 11$. $\mathrm{F}_{2}$ fold axis; 12. Axis of tubular fold; 13. Shear zones parallel to primary bedding; 14. Thrust faults; 15 . Strike-slip faults. Modified from Vial (1980) and Vieira (1992). 
carbonate mineral or solid carbonaceous matter (?), probably due to accidental capture during the fluid trapping.

Dark monophase inclusions, at room temperature, frequently coexist with the above two-phase aqueous inclusions, but in a much lower frequency than the latter.

Both types of inclusions show polyhedral outlines or irregular shapes, with their longest dimension ranging from $10 \mu \mathrm{m}$ up to $40 \mu \mathrm{m}$.

Three main types of microthermometric behavior are distinguished in the bubble of the two-phase aqueous inclusions during the low temperature runs: (1) nucleation of a $\mathrm{CH}_{4}$ gas phase within the bubble at temperatures $<-100^{\circ} \mathrm{C}$ and its subsequent homogenization, to the liquid state, at temperatures ranging from -134.2 to $-82.6^{\circ} \mathrm{C}$, accompanied occasionally by the sublimation of a solid $\mathrm{CO}_{2}$ phase at temperatures between -90 and $-77.8^{\circ} \mathrm{C}$; (2) the same previous behavior at temperatures $<-100^{\circ} \mathrm{C}$, but with melting of solid $\mathrm{CO}_{2}$ preceding the $\mathrm{CH}$ homogenization $\left(-97.6\right.$ to $\left.-84.7^{\circ} \mathrm{C}\right)$ and varying from -108.3 to $85.3^{\circ} \mathrm{C}$; (3) melting of solid $\mathrm{CO}_{2}$ varying from -74 to $-61.2^{\circ} \mathrm{C}$, followed by homogenization of $\mathrm{CO}_{2}^{2}$, in the liquid state, between -67.8 and $-18.2^{\circ} \mathrm{C}$, in the presence of clathrates, or between -19.9 and $5^{\circ} \mathrm{C}$, in the absence of clathrates. Very rarely, individual inclusions showed a sequence of $\mathrm{CH}_{4}$ homogenization, melting of solid $\mathrm{CO}_{2}$, and $\mathrm{CO}_{2}$ homogenization. Based on the above microthermometric behaviors, a mixture of variable proportions $\mathrm{CH}_{4}$ and $\mathrm{CO}_{2}$ may be expected for the bubble of the two-phase aqueous inclusions (van den Kerkhof 1990). This was confirmed by LRM analyses in the bubble of individual inclusions with different microthermometric behaviors, which additionally yielded subordinate amounts of $\mathrm{N}_{2}$ and traces of $\mathrm{H}_{2} \mathrm{~S} / \mathrm{HS}$ (Fig. 2A).

Salinity values for the aqueous phase of these inclusions were roughly estimated between 3 and 6 wt. $\% \mathrm{NaCl}$ eq., based on the combination of the melting temperatures of clathrates, which took place within the interval 12.4 to $22.3^{\circ} \mathrm{C}$, and representative $\mathrm{CH}_{4}$ isochores for these inclusions, as explained in Thomas and Spooner 1988. A few measurements of the total homogenization of the twophase aqueous inclusions yielded values ranging from 160 to $340^{\circ} \mathrm{C}$, in the liquid state.

The only phase change shown by the monophase inclusions was that of homogenization, into the vapor state, at temperatures between $-81.2^{\circ} \mathrm{C}$ and $-82.7^{\circ} \mathrm{C}$. This behavior, in conjunction with LRM data, constrains the composition of this inclusion fluid to $\mathrm{CH}_{4} \pm \mathrm{CO}_{2}\left(\mathrm{H}_{1}\right.$ inclusions; van den Kerkhof 1990).

\section{CARBON AND OXYGEN ISOTOPE RESULTS Carbon} Isotopes Carbonates in the banded carbonaceous metasedimentary host typically show markedly heavier carbon isotope compositions, compared to carbonates in the gold-related carbonatesulfide altered zones and gold-sulfide breccia and veins. The $\delta^{13} \mathrm{C}$ values of siderite and calcite in the carbonaceous host range from -4.3 to $-1.7 \%$, with one value at $-7.1 \%$ for ankerite, whereas ankerite from carbonate-sulfide altered zones has values of -8.0 and $-7 \%$ and siderite -7.6 and $-6 \%$ (Table 1; Fig. 2B). Rare calcite and dolomite in the carbonate-sulfide zones showed similar values of $\delta^{13} \mathrm{C}$ of ankerite and siderite: $-7.1 \%$ (calcite) and $-8.0 \%$ (dolomite).

Carbonates in the gold-sulfide breccia and veins were isotopically similar to those in adjacent carbonate-sulfide altered zones: -8.1 to $6.9 \%$ (ankerite), -6.3 to $-6.2 \%$ (siderite), $-5.5 \%$ (calcite), and $7.1 \%{ }^{\circ 0}$ (dolomite). Additionally, a $\delta^{13} \mathrm{C}$ value of $-7.9^{8} \%$ was obtained for calcite from a barren quartz vein.

The heaviest value of $\delta^{13} \mathrm{C}\left(-0.2^{\circ} \%\right)$ was obtained for calcite from veinlets that crosscut the carbonaceous host, away from the mineralized carbonate-sulfide zones (Table 1; Fig. 2B).

Oxygen Isotopes The range of $\delta^{18} \mathrm{O}$ values obtained for carbonates from the banded carbonaceous metasedimentary rock and from an enclosed barren carbonate veinlet, between $12.8 \%$ and $16 \%$ , overlaps the interval of 10.6 to $15.2^{\circ} \%$ for carbonates from mineralized zones, although there is a slightly larger variation in the latter (Fig. 2B). A $\delta^{18} \mathrm{O}$ value of $13.2^{\circ} \%$ for calcite from a barren quartz vein (sample CURPX3; Table 1) falls within the above range of $\mathrm{d}^{18} \mathrm{O}$ values for carbonates from the mineralized zones and host rock.

DISCUSSION The primary nature of the two-phase $\mathrm{H}_{2} \mathrm{O}-\mathrm{CH}_{4}$ $\mathrm{CO}_{2}-\mathrm{N}_{2}-\left(\mathrm{H}_{2} \mathrm{~S} / \mathrm{HS}^{-}\right)$inclusions imply that they may be regarded as the closest representative of the fluid which interacted with the

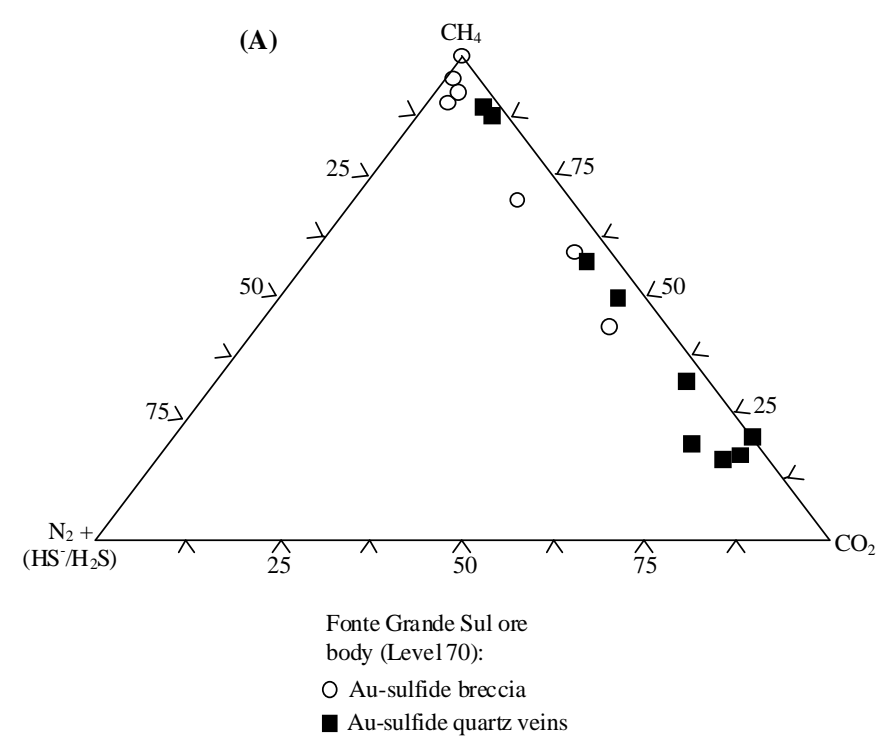

(B)
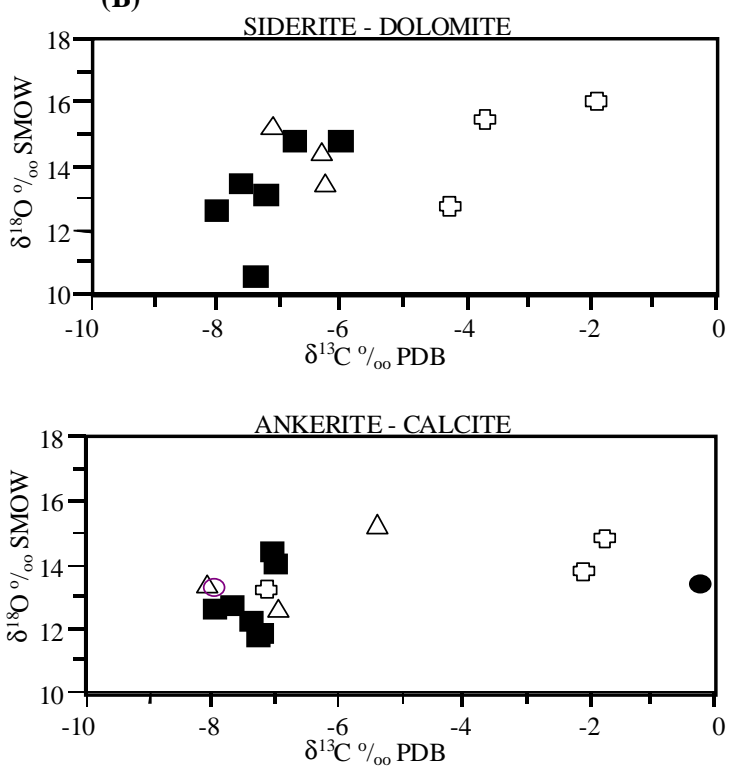

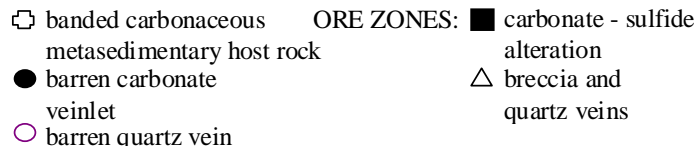

Figure 2-(A) Composition of the bubble obtained by Laser Raman microspectroscopy in the two-phase aqueous inclusions investigated in goldbearing quartz-carbonate veins and breccias within the carbonate-sulfide altered zones. $(B) \delta^{13} C$ versus $\delta^{18} O$ values for siderite, ankerite, calcite and dolomite in the carbonaceous host rock, ore zones and barren vein samples of the Cuiabá Mine.

carbonaceous wallrocks and probably precipitated gold at the Cuiabá Mine. Bulk composition estimates for these inclusion fluids defined this fluid as dominantly aqueous, of low salinity $(<1.5 \mathrm{~mol} \%)$, with variable concentrations of $\mathrm{CO}_{2}(0-11.4 \mathrm{~mol} \%), \mathrm{CH}_{4}(1.5-10.2$ mol\%), subordinate $\mathrm{N}_{2}(0-0.7 \mathrm{~mol} \%)$, and traces of $\mathrm{H}_{2}^{4} \mathrm{~S} / \mathrm{HS}^{-}$. 
Table 1- $\delta^{13} \mathrm{C}$ and $\delta^{18} \mathrm{O}$ values measured in ankerite (ank), siderite (sid), calcite (cc), and dolomite (dol) in the carbonaceous metasedimentary host, orebodies and barren samples of the Cuiabá Mine. $C b=$ carbonates; sulf $=$ sulfides; qtz=quartz.

\begin{tabular}{|c|c|c|c|c|c|}
\hline Samples & Rok type/Location & $\begin{array}{l}\delta^{13} \text { Ccc-ank } \\
\% \text { V-PDB }\end{array}$ & $\begin{array}{l}\delta^{18} \text { Occ-ank } \\
\% \text { V-SMOW }\end{array}$ & $\begin{array}{l}\delta^{13} \text { Csid-dol } \\
\% \text { V-PDB }\end{array}$ & $\begin{array}{l}\delta^{18} \text { Osid-dol } \% \\
\text { V-SMOW }\end{array}$ \\
\hline CB247 & Host/Galinheiro ore body-N7 & $-2.11(\mathrm{cc})$ & $13.72(\mathrm{cc})$ & $-4.27(\mathrm{sid})$ & $12.76(\mathrm{sid})$ \\
\hline CB28C & Host/Serrotinho ore body-N5 & -7.14 (ank) & 13.24 (ank) & $-3.70($ sid $)$ & $15.44(\mathrm{sid})$ \\
\hline CB95 & Host/Cantagalo ore body-N11 & $-1.74(\mathrm{cc})$ & $14.80(\mathrm{cc})$ & $-1.85(\mathrm{sid})$ & 15.99 (sid) \\
\hline CB67A & Cb-sulf zones/Fonte Grande Sul ore body-N7 & -7.22 (ank) & 11.87(ank) & & \\
\hline CB67B & Cb-sulf zones/Fonte Grande Sul ore body-N7 & -6.99 (ank) & 14.05 (ank) & $-7.40($ sid $)$ & $10.60(\mathrm{sid})$ \\
\hline CB77C & Cb-sulf zones/Fonte Grande Sul ore body-N7 & -7.98 (ank) & 12.60 (ank) & $-8.00(\mathrm{dol})$ & $12.60(\mathrm{dol})$ \\
\hline CB49C & Cb-sulf zone/Fonte Grande Sul ore body-N7 & -7.68 (ank) & 12.73 (ank) & $-6.00(\mathrm{sid})$ & 14.80 (sid) \\
\hline CB-BAL/N11 & Cb-sulf zones/Balancão ore body-N11 & -7.31 (ank) & 11.76 (ank) & $-7.20($ sid $)$ & $13.14(\mathrm{dol})$ \\
\hline CB-SERR/N5 & $\mathrm{Cb}$-sulf zones/Serrotinho ore body-N7 & $-7,07(\mathrm{cc})$ & $14.44(\mathrm{cc})$ & $-6.74(\mathrm{sid})$ & 14.84 (sid) \\
\hline CB245 & Cb-sulf zone/Galinheiro ore body-N11 & -7.42 (ank) & 12.26 (ank) & $-7.61(\mathrm{sid})$ & 13.45 (sid) \\
\hline CURPX1A & Breccia/Fonte Grande Sul ore body-N7 & -6.94 (ank) & 12.62 (ank) & $-7.08(\mathrm{dol})$ & $15.24(\mathrm{dol})$ \\
\hline CURPX 1B & Breccia/Fonte Grande Sul ore body-N7 & -8.07 (ank) & 13.41 (ank) & & \\
\hline CB202 & Qtz-cb-Au vein/Fonte Grande Sul ore body-N7 & & & $-6.24(\mathrm{sid})$ & $13.44(\mathrm{sid})$ \\
\hline CB202 & Qtz-cb-Au vein/Fonte Grande Sul ore body-N7 & $-5.49(\mathrm{cc})$ & $15.26(\mathrm{cc})$ & $-6.33($ sid $)$ & 14.47 (sid) \\
\hline CURPX3 & Barren qtz-cb vein/Fonte Grande Sul ore body-N7 & $-7.95(\mathrm{cc})$ & $13.25(\mathrm{cc})$ & & \\
\hline CB247 & Barren cb veinlet/Fonte Grande Sul ore body-N7 & $-0.22(\mathrm{cc})$ & $13.37(\mathrm{cc})$ & & \\
\hline
\end{tabular}

Considering that field and petrographic evidence suggests that the carbonaceous matter was generally consumed during carbonate alteration, and that $\mathrm{CH}_{4}$ and $\mathrm{CO}_{2}$ are ubiquitously present in significant concentrations in the inclusion fluids studied, the possibility exists that hydrolysis/oxidation of the carbonaceous matter in the wallrocks, upon interaction with the hydrothermal fluid, may have influenced the composition of the fluid, subsequently trapped during alteration and veining. $\mathrm{CO}_{2}$ and $\mathrm{CH}_{4}$ may have formed, for example, via hydrolysis reactions of the carbonaceous matter (1) $2 \mathrm{C}+2 \mathrm{H}_{2} \mathrm{O}=$ $\mathrm{CO}_{2}+\mathrm{CH}_{4}$ or, at a lower oxidation state, by the reaction (2) $\mathrm{C}+2 \mathrm{H}_{2} \mathrm{O}$ $=\mathrm{C}_{4}+\mathrm{O}_{2}$, which could have provided the requisite $\mathrm{CO}_{2}$ for carbonatization (reaction 1) and/or enriched the ore fluid in $\mathrm{CH}_{4}^{2} \pm \mathrm{N}_{2}$ (reaction 2).

The $\delta^{13} \mathrm{C}$ and $\delta^{18} \mathrm{O}$ data obtained on carbonates from the host rock, mineralized and barren zones of the Cuiabá Mine, allow a further assessment of this question. If the hydrothermal fluid contained no original $\mathrm{CO}_{2}$, and were of sufficiently high oxidation state and quantity (i.e., water/rock ratio) to oxidize reduced wallrock carbon, then the $\delta^{13} \mathrm{C}_{\mathrm{CO} 2}$ should approximate the $\delta^{13} \mathrm{C}_{\text {WALLRoCK CARBoN }}$. The $\delta^{13} \mathrm{C}$ values of carbonate precipitated from the resulting fluid, and detected in the wallrocks, would then reflect temperature-dependent fractionation factors. Alternatively, if the oxidation state of either the original hydrothermal fluid, or the evolved hydrothermal fluid, was sufficiently low to stabilize $\mathrm{CH}_{4}$, then the $\delta^{13} \mathrm{C}$ value of carbonate precipitated from the fluid would depend also on the $\mathrm{CH}_{4} / \mathrm{CO}_{2}$ ratio of the fluid; values of $\delta^{13} \mathrm{C}$ would have been higher, even positive, with increasing $\mathrm{CH}_{4} / \mathrm{CO}_{2}$. If the oxidation state of the fluid happened to be buffered by graphite-bearing wallrocks according to reaction (1) above, then the $\delta^{13} \mathrm{C}$ of isotopically-equilibrated $\mathrm{CO}_{2}$ would most likely have been $<-12 \%$ o (e.g., Bottinga 1969). In all cases, the $\mathrm{d}^{18} \mathrm{O}$ values of the carbonate in veins and hydrothermally altered wallrocks and breccias depended on the temperature and isotopic composition of the fluids, as determined by previous water/rock interaction and isotope exchange.

As Figure 2B demonstrates, the $\delta^{13} \mathrm{C}$ compositions of carbonate in sedimentary wallrocks and in altered and mineralized veins and wall rocks are markedly different, suggesting an external source(s) for the fluid-derived $\mathrm{CO}_{2}$, different modes of carbonate formation, and/or carbon isotope variation of $\mathrm{CO}_{2}$ due to equilibration with $\mathrm{CH}_{4}$ in the fluid. If equilibration with $\mathrm{CH}_{4}$ in the reacted fluid were a factor, then the carbon isotope composition of precipitated carbonate must reflect a maximum value for $\delta^{13} \mathrm{C}$ for the carbon source, inasmuch as $\mathrm{CH}_{4}$ is depleted in ${ }^{13} \mathrm{C}$ relative to $\mathrm{CO}_{2}$ at equilibrium (e.g., Richet et al. 1977).

The most straightforward interpretation of the marked differences in $\delta^{13} \mathrm{C}$ between carbonate in the metasediments and that in the veins, breccias, and altered zones is that the formers are essentially marine carbonates. The near-zero permil $\delta^{13} \mathrm{C}$ values are certainly in agreement with this suggestion, whereas the lower values $(-7.1$ and $4.3 \%$ o) could represent some isotopic exchange with hydrothermal fluids. The rather narrow variation in $\delta^{13} \mathrm{C}$ of gold-related alteration and breccia/vein-associated carbonate, with significantly lower values of $\delta^{13} \mathrm{C}$, including that of calcite in a barren vein, than that of the metasedimentary carbonate, suggests a relatively homogeneous isotopic composition for the hydrothermal fluid $\mathrm{CO}_{2}$ and either equilibration with carbonate and reduced carbon reservoir (e.g. mantlederived magma; Taylor 1987).

CONCLUSIONS Fluid inclusion and carbon isotope data indicate that the original fluid responsible for carbonate-sulfide alteration and gold deposition at the Cuiabá Mine was probably of a low salinity $\mathrm{H}_{2} \mathrm{O}$ $-\mathrm{CO}_{2}$ solution, typical of fluids related to the formation of greenstonehosted mesothermal lode-gold deposits, which incorporated significant concentrations of $\mathrm{CH}_{4}$ related to hydrolysis of the carbonaceous matter during vein-fluid/wallrock interaction. On the basis of the carbon isotope data, sedimentary carbonates, probably of marine origin, are readily distinguished from those carbonates formed by reaction between $\mathrm{CO}_{2}$-bearing vein fluids and wall rocks. Vein fluid $\mathrm{CO}_{2}$ was relatively homogeneous in isotopic composition, suggesting either equilibration with carbonate or reduced carbon reservoir (e.g., mantlederived magma).

The addition of $\mathrm{CH}_{4}$ during fluid-rock carbon interaction may have caused a sharp decrease in $f \mathrm{O}_{2}$ of the fluid which, as a consequence, destabilized gold-bearing sulfur complexes, liberating $\mathrm{S}^{-2}$ for the formation of $\mathrm{Fe}$ sulfides, and triggered gold deposition.

Acknowledgements Mr. Adrian Timbal (Geological Survey of Canada, Ottawa) and Mr. Dailto Silva (Institute of Geoscience/ UNICAMP, Brazil) are thanked for the invaluable assistance with stable isotope and Laser Raman analyses, respectively. Our thanks are also extended to the anonymous referee whose comments helped to improve the paper. This research was funded by the Fundação de Amparo à Pesquisa do Estado de São Paulo through the grants \# 97/ 00780-1 and 1998/13807-8.

\section{References}

Al-Assam I.S., Taylor B.E., South B.S. 1990. Stable isotope analysis of multiple carbonate samples using selective acid extraction: Isotope Geoscience, 80:119-125.

Bottinga, Y. 1969. Calculated fractionation factors for carbon and hydrogen isotopic exchange in the system calcite-carbon dioxide-graphite-methane-hydrogen-water vapour. Geochim. Cosmochim. Acta, 33:41-64.
Lobato L.M., Vieira F.W.R., Ribeiro-Rodrigues L.C., Pereira L.M.M., Menezes M., Junqueira P.A., Martins Pereira S.L. 1998. Styles of hydrothermal alteration and gold mineralization associated with the Nova Lima Group of the Quadrilátero Ferrífero: Part I. description of selected gold deposits. Rev. Bras. Geociências, 28(3):339-354. 
Marshak S., Alkmin F.F., Jordt-Evangelista H. 1992. Proterozoic crustal extension and generation of dome-and-keel structure in na Archean granite-greenstone terrane. Nature, 357:491-493. McCrea J.M. 1950. On the isotopic chemistry of carbonates and a paleotemperature scale.
Journal of Chemical Physics, 18:849-857.

Ribeiro-Rodrigues L.C. 1998. Gold in Archaean banded iron-formation of the Quadrilátero Ferrífero, Minas Gerais, Brazil - the Cuiabá Mine. Aachen University of Technology, Aachen, Germany, Ph.D. Thesis, Aachener Geowissenschaftliche Beitrage, Band 27, 264p.

Richet P., Bottinga Y., Javoy M. 1977. A review of hydrogen, carbon, nitrogen, oxygen, sulphur, and chlorine stable isotope fractionation among gaseous molecules. Ann. Rev. Earth Planet. Sci., 5:65-110.

Taylor B.E. 1987. Stable isotope geochemistry of ore-forming fluids. In Kyser, T.K. (ed.) Short Course in Stable Isotope Geochemistry of Low Temperature Fluids. Mineralogical Association of Canada, 13:337-445.

Thomas A.V. \& Spooner E.T.C. 1988. Fluid inclusions in the system $\mathrm{H}_{2} \mathrm{O}-\mathrm{CH}_{4}-\mathrm{NaCl}-\mathrm{CO}$ from metasomatic tourmaline within the border unit of the Tanco zoned granitic pegmatite, S.E. Manitoba. Geochim. Cosmochim. Acta, 52:1065-1075.
Toledo C.L.B. 1997. Controle estrutural da mineralização aurífera na Mina de Cuiabá, Setor Noroeste do Greenstone Belt Rio das Velhas, Quadrilátero Ferrífero, MG. Inst. de Geociências, UNICAMP, Campinas, M.Sc. Dissertation, 167p.

van den Kerkhof A. M. 1990. Isochoric phase diagrams in the systems $\mathrm{CO}_{2}-\mathrm{CH}_{4}$ and $\mathrm{CO}_{2}-$ $\mathrm{N}_{2}$ : application to fluid inclusions. Geochim. Cosmochim. Acta, 54:621-629. Velho S.A. Internal Report, $21 \mathrm{p}$.

Vial D.S. 1988. Mina de Ouro de Cuiabá, Quadrilátero Ferrífero, Minas Gerais. In C. Schobbenhaus \& C.E.S. Coelho (eds.) Principais Depósitos Minerais do Brasil. Brasília, DNPM, 3, 420-443.

Vieira F.W.R. 1992. Geologia da Mina de Cuiabá, níveis 03 e 04. Mineração Morro Velho S.A. Internal Report, $23 \mathrm{p}$.

Contribution IGC-113

Contribution IGC-113
Received March 3, 2000 Accepted for publication May 15, 200 